\title{
Images of America in unified Germany
}

Stefan Fröhlich

Department of Political Sciences

Bonn University

BONN

Germany

\begin{abstract}
Images of America in unified Germany

The following article analyses American cultural influence on Germany especially in the period afier unification. "Wendeliteratur" as well as new cultural relations and institutions are emphasised. The role of the mass media, which have conveyed the image of the American way of life, American products and services to East German is also discussed. For a better understanding of these images the author takes a closer look at what "Americanisation" really means to European cultures. All too often cultural observers state that Europe has been exposed to a pernicious Americanism. Such attitudes, however, should caution us against a too negative image of America. Although German-American relations during the post-war period had their ups and downs, West Germans on the whole developed a positive image of America, internalising American cultural elements as part of their own identification. The East Germans, on the other hand, it will be argued, while developing an enthusiasm for America at the time of reunification, turned more and more to a very critical, rather cynical view of American culture, thus letting euphoria fade to a very rational image.
\end{abstract}

\section{Introduction - America at the centre}

The twentieth century, it has often been said, is the American century. As a matter of fact, America has moved toward centre stage, while Europe finds itself on the receiving end of a wave of American culture that washes across the globe. At the end of this century "globalisation" has become the keyword and to many people it is synonymous with Americanisation. All too often, cultural observers ask whether Europe has been exposed to a pernicious Americanism. In alarm or exhilaration they have been pointing to an influx of American cultural products, tangible or abstract, goods or ideas, which has led to an Americanisation of Europe's cultures.

Such attitudes, however, should caution us against having too negative an image of America. Everything that strikes Europeans about America is really no more 
than a radical version of trends and developments indigenous to Europe. The spirit of optimism and a belief in progress, in the ongoing democratisation of humanity, of course, are characteristically American, but they are not genuine attributes of an American cast of mind; they are products of European culture, of the European philosophy of the Enlightenment. Apart from that the European imagination had already invented a mythical West before America was discovered. To a certain extent America has merely kept European collective dreams alive. Even today it still holds up before our eyes a gigantic screen for the projection of fantasies which are European as much as they are American. It provides a repertoire for identification with a world that derives its attraction from the very fact that America is conceived as the "New World", as a non-Europe, that it provides a counterpoint to our culture. That is precisely why attitudes towards America have never become a matter of consensus in Europe.

In other words, America shows us, in pure culture, only what Europe has never really managed to bring to full fruition, because it interpreted this "modernisation process" as a process of demystifying the "old world". This reading of America parallels the one which was developed in the 1950s as an essentially Toquevillian idea - the idea that a liberalism that can be traced back to John Locke had sunk its roots in America more deeply than anywhere in Europe, where rival ideologies and the dialectics of class hindered the development of truly modern nations. This spirit of modernity, however, was established in America. Europe has never been able to cope fully with this spirit as its different societies and cultures developed new organisms with their own rules of growth.

\subsection{Americanisation and what it really means to us}

Americanism or Americanisation - these are catchwords, which have been describing the American influence on Europe since the golden 1920s of this century (Basler, 1930:142-147). The terms denoted very different time streams, which generally were synonymous with the term modernisation. Americanisation and a cultural practice in which the diversity of social and ethnic groups in the United States were transformed into a unified nation. Many believed that one day this homogenising dynamism would catch the whole world.

The images of America were dominated by stereotypes, which from time to time were restated anew and which were very often interpreted as differently as the word and pictorial metaphors that carried them (Lüdke et al., 1996:9). Those stereotypes can be summed up by the following keywords: feasibility of nature and history; predominance of American technology; "American Way of Life"; America - a mass culture; America - a land without culture. For each of these stereotypes there are different national answers and applications. All these stereotypes are, however, somehow present in our lives, part of our imagination - 
in this century, especially in the post-war period, to a greater extent than ever before. In that sense our lives unmistakably have undergone an Americanisation.

\section{The history of German-American relations}

Over generations Germany has acquired a set of cultural codes that allows it to understand American cultural products, to appreciate them, and to consume them as if we were Americans. Germans have no more trouble deciphering American messages - be they commercials, television programs, or Hollywood movies than average Americans, and after the Wall fell, the mass media stared in at the East Germans as well, constructing an image of them from the Western point of view. That is not naturally so. Again and again generations in Germany have parted ways in their appreciation of American culture:

Time and time again younger generations ... have had to explain to their elders what was so appealing about jazz music, about Laurel and Hardy, about blue jeans and sneakers, about Western movies. Principles of form and of narrative technique, contexts of association - we all have had to make them our own (Kroes, 1996:170 f.).

And we do this by receiving American culture in many varieties: by copying Americans without due consideration; by a conscious act of cultural appropriation, a creative identification with admired examples; or by returning to a kind of adolescent dream when the world still had endless potential.

\subsection{The German Amerikabild}

Since the Second World War, German-American cultural exchanges have become so intensive that one cannot distinguish between what is genuinely American or foreign, and what is German. More than in any other country the United States has provided the leading and dominating culture in Germany. One explanation for this is of course the new Western integration of the Federal Republic after the war and the diverse political, economic, military and cultural interconnections between the two countries. This phenomenon alone, however, does not explain, why many Germans of the post-war generation admired the US as a shining example. There are other elements such as the deep gratitude of many for the reconstruction help, for the Marshall Plan, airlift, CARE packets, and the "identification of the defeated with the victor" (Mitscherlich \& Mitscherlich, 1977).

With regard to the German Amerikabilder, the fascination with American everyday culture is no less important. America is omnipresent in almost every area of life for German citizens: Jeans, parka and sweatshirts, cornflakes, ketchup, chewing gum, hamburgers and Coca Cola, Mickey Mouse and Donald 
Duck, James Dean and Gary Cooper, Michael Jackson and Tina Turner, go-ins, sit-ins, happy birthday, okay and bye bye - let us stop here. To distinguish between what is German and what is American seems to be illusionary, a fact that has already evoked some cultural-critical protest against the "Coca-Colonisation" of German or European culture. In Max Frisch's famous novel Homo Faber (1957), for instance, the hero formulates an essential criticism of the "American way of life" - a criticism that concentrates European prejudices and aversions towards an Americanisation in a few emotive words:

Schon was sie essen und trinken, diese Bleichlinge, die nicht wissen, was Wein ist, diese Vitamin-Fresser, die kalten Tee trinken und Watte kauen und nicht wissen, was Brot ist, dieses Coca-Cola-Volk, das ich nicht ausstehen kann. ... Was Amerika zu bieten hat: Komfort, die beste Instalation der Welt, ready for use, die Welt als amerikanisches Vakuum, wo sie hinkommen, alles wird Highway, die Welt als Plakat-Wand zu beiden Seiten, ihre Städte, die keine sind, Illumination, am anderen Morgen sieht man die leeren Gerüste, Klimbim, infantil, Reklame für Optimismus als Neon-Tapete vor der Nacht und vor dem Tod (Frisch, 1957:130 f.).

This citation with its debasement of the American way of life will of course be rejected by most of the younger generation as outdated, old-fashioned, and incomprehensible. Nevertheless, these stereotypes of anti-Americanism are still widely known; there are critics who call America's contemporary culture "postmodern", because as they see it, the country has lost its innocence and sense of invention. It has become aware of its own underlying rules of transformation, of its modularising penchant, its freedom to fragment and rearrange. In this sense America has grown old in the awareness that everything has already been done, that every experiment has already been tried.

Of course such criticism must be qualified by the fact that after 1945, and also after unification, every form of German nationalism has been discredited and that this has led to an increasing similarity between the cultures, or let us say, to a German alignment with Western standards. One can analyse these processes from different point of views: as Diktat of American occupation politics after the war and warning against the old Deutschtümelei, as the result of international political and economic interdependence, or as a process of cultural change. Here, however, we will give the problem of domestic and foreign images of Germany and the influence of an omnipresent American Leitkultur on the German images of America priority treatment.

Since the Second World War several generations have grown up in West Germany - generations for whom the national-cultural distinctions between Germany and the United States of past generations have been irrelevant. More characteristic was the distance from the Eastern block and individual minorities 
(Ausländerfeindlichkeit). Whether and how the reception of certain elements of the American everyday culture has finally changed the German Amerikabilder, however, is not a question that allows a simple answer. There is no sweeping Americanisation in any area of life; what comes to Europe are single elements that have been taken out of their original contexts. In other words, cornflakes do not make a German or an American breakfast. Behind an apparent omnipresence of the typically American, selective clips are hiding, which will never make you grasp the diversity of the American life. Apart from that, the Amerikabild that is conveyed by the media is moulded by autostereotypes made in USA. We do not consume a selfmade Fremdbild but a Selbstbild that has been produced in America. As we see Americans and America in TV movies, so the Americans see themselves - at least in the fantasy produced by the media, and that is - as we all know - dependent on popular myths (Mikos, 1987:61-69).

Nevertheless, despite these fragmented and changing influences, knowledge and imagination of America have multiplied during the past decades, and the USA has become a natural part of German everyday life. Series productions like "Dallas" or "Dynasty", which reduce the American everyday reality to a few synthetic elements, do have an American effect through requisites, milieus and sceneries; in German everyday life, however, they are received not as foreign but as intimate entertainment.

\subsection{German-American relations before unification}

There are many possible approaches to the origin and history of the prevalent German Amerikabilder in our context. A chronicle of German-American relations and encounters in a historical, political, and critical sense offers a solid and indisputable basis of facts, but risks projecting historical events almost unbrokenly on to a pictorial world. There are already a lot of historical and political studies on this subject. A sociological or social-psychological examination could try the construction of the ideal types that different Amerikabilder (Anti-Americanism, Atlanticists, Western- and Folk-fans etc.) represent. Such a method, however, risks favouring or producing new stereotypes. For this reason, the most appropriate approach seems to be to focus on certain phases, which have become part of our everyday knowledge as catchy and characteristic events. These events are determined by a popular chronology, which prefers to internalise historical changes in decades (the fifties) or examines events that have influenced the collective experience of life of different groups or movements (Stunde Null, die 68er). One should keep in mind of course, that such seemingly selective caesurae conceal the continuity of the historical process, which is so important for the persistence of images. 
What are these characteristic events that finally moulded the German Amerikabild? Very briefly they are the following: After the war and during the fifties it was the identification with the victor, who soon presented himself as the generous friend $(\mathrm{Ami})$ and not as the vindictive recipient. Europeans who went to America in the immediate post-war period revealed - often with reluctance virtues in the country that seemed to have been lost in Europe. Sometimes even the mere contact with Americans in Europe was sufficient. One of the most widely read authors in those days, Curzio Malaparte, published a book in 1950 (Die Haut) that was almost a declaration of love for America and the Americans:

Ich mag die Amerikaner gern, weil sie gute Christenmenschen sind. ... Ihr Sinn für Menschlichkeit, ihre Großzügigkeit, die Ehrlichkeit und reine Einfalt ihrer Ideen, ihrer Empfindungen, die aufrichtigkeit ihres Gebarens ... gaben mir die Hoffnung auf ein besseres Menschsein (Malaparte, 1950:18 f.).

But it was not only the American concern for freedom in the world that improved their image in Europe. It was also the Kulturnation America: American novelists like Ernest Hemmingway, John Steinbeck and William Faulkner were seen as representatives of a new, fascinating literature. German and other European theatres performed plays by Tennessee Williams, Thornton Wilder and Eugene O'Neill. In another wave, American painters, orchestras, conductors and soloists gained a leading position as well. The United States not only presented itself as a great military and economic power but also as one of the dominant countries in many cultural fields. The European disdain of former days was no more.

On the other hand, there were already critical voices. The new anti-Americanism of those years was, however, fundamentally different from that of the past. It was also separated into "leftist" and "rightist" criticism. The leftist criticism most profoundly expressed by prominent voices such as Jean-Paul Sartre or Simone de Beauvoir, was the result of the East-West conflict; in Germany the most obvious example was the book of Leo L. Mathias (1953) called Die Entdeckung Amerikas Anno 1953, which tried hard to pull America to pieces. The rightist critics were afraid of an Americanisation that threatened European individuality, from industrial management to the mechanisation of German kitchens, from automation of production plants to food alteration to preserved food. It was some time before Europeans realised that the "Americanisation", although it did not accidentally start in America, was implied by the very nature of the modern society and its thirst for rationalisation. Golo Mann was quite right when he realised that "America was only ahead of a general development" (Mann, 1961: 11).

During the sixties, the decade when TV was coming into almost every German household, a very ambivalent mood characterised the German Amerikabild. The 
former, almost blind identification of many Germans with the American victor, the enthusiasm for reconstruction as a way to dismiss the confession of guilt, the restorative concentration on the private sphere, all this could not be upheld in this decade without reservation. The Amerikabilder in German society were polarised as never before. This does not mean there was a popular, but simplified split into one-dimensional pro- or anti-American attitudes, as expressed by certain events (Kennedy's "Ich bin ein Berliner" speech on the one hand, and the Vietnam War on the other). On both sides the images were ambivalent, and in any confrontation with America, Germans also argued amongst themselves.

The emotional pro- or anti-Americanism disappeared in the seventies. This was only partly because of the new foreign policy and domestic orientations. The hopes of the revolution of the $68 \mathrm{er}$ movement were followed by movements that turned to the private, the inner, and more concrete social-political problems. In German literature something like a Tendenzwende was taking place in the name of what German authors called a "new subjectivity". Its main feature was a more autobiographical style of writing that chose existential borderline situations as its central theme. Symptomatic in this context is the change of the literary Amerikabild, as for example in Peter Handke's book Der kurze Brief zum langen Abschied (1972). In this novel the frustrated protagonist chooses America as the place where he may leave his fearful life story behind. Once again America is presented as the place for a new beginning, for new hopes. In an interview Handke expressed his feelings with regard to this place as follows: "Amerika ist das einzige, von dem man heutzutage sagen kann, es sei die Fremde, es sei die andere Welt. Für mich ist es halt auch eine Traumwelt, in der man sich selber ganz neu entdecken muß, in der man selbst ganz neu anfangen muß" (Karasek, 1972:85-90).

This turn to subjectivity of course was definitely not apolitical. In politics, activity turned from university campuses to other spheres of life, to the new social movements, which followed very concrete ideas or were sparked off by concrete conflicts (single-issue movements): anti-nuclear power, peace and disarmament, environment etc. These movements discovered a new America, not the economic and military superpower, but the country with a long tradition of grass roots democracy and a creative extraparliamentary opposition that represented concerns similar to the new social movements in the Federal Republic.

The eighties were marked by several events - the NATO decision to deploy Cruise missiles and Pershings in several European countries; the military concept of a war limited to Europe; the cynical advertisement in New York's World Trade Center: "Visit Europe while it still exists" - that stirred up German-American relations and encouraged an open anti-Americanism and anti-militarism, which, in this form, had been unknown in the German society before (Irions, 1984:91-94). 
It was suddenly clear that despite all the familiar closeness in this relationship there would always be some negative variants in the German Amerikabild, using the well-known theme of the continent without culture and with no sense of history.

\section{German-American cultural relations after unification}

\subsection{A new international environment}

Paradoxically, this anti-American mood seemed to live on, at least for a while, after unification in a way that nobody could ever have forseen. But with the collapse of the Eastern block, the implosion of the Soviet Union, the (supposed) victory of democracy, in short: with the decrease of the threat from the East, long lasting concepts of the enemy were destroyed, while the complementary image of America as the protecting power started to lose its importance. Besides that, there was erosion in the transatlantic relationship of much deeper dimensions. Increasing disinterest, erosion of personal networks, the change of generations, a new focus on domestic problems on both sides, erratic and unstable political positions: in a word, as Werner Weidenfeld put it recently, in German/EuropeanAmerican relations, the end of former Selbstverständlichkeiten (naturalness) had come (Weidenfeld, 1996:9). For a while Germans seemed to want to replace the Tocqueville-paradigm (1832) of the two super powers controlling the world with the paradigm of the French writer Victor Hugo: Europe, Hugo wrote in 1848, should set itself next to the United States as a power capable of acting.

The key event, of course, was German unification, and the central question for our neighbours, as well as for the United States and Russia was, what consequences it might have for German Selbst- und Fremdbilder. The unification process must be seen and judged against the background of two opposite developments in Central and Eastern Europe. In Eastern Europe the implosion of the Soviet Union has triggered a renaissance of nationalistic movements for autonomy in the New Independent States. The former socialist states have detached themselves from Moscow and orientated themselves towards the West. The parallel processes of integration and deepening within the EU have made the traditional Freund- and Feindbilder almost obsolete and replaced them by an increase of internal Feindbilder. In Germany ethnic minorities, mainly emigrants and Ubersiedler from the Eastern countries have been affected by this development. For a long transition period, united Germany will, in a way, remain separated, as long as the destroyed self-esteem of the East Germans faces the self-consciousness of the rich West Germans, which, of course, has a lasting impact on the way East Germans construct an image of the Western "philosophy" in general, and America in particular. As Christa Wolf, one of the leading authors in the former GDR and during the transition period, a kind of failed Kultfigur, 
has put it very bluntly: "Entfremdung folgt auf Entfremdung. Wer fragt noch, wo unser Lächeln geblieben ist? Es wurde zwischen der heillosen Vergangenheit und der für viele perspektivlosen Zukunft zerquetscht" (Bundesministerium für Bildung und Wissenschaft, 1995:16).

Many authors reflect the present very critically, observing an increasing Ausländerfeindlichkeit, and the attraction and power of money in a capitalistic world. To a certain extent, this has led to a distinctive Heimatbewußtsein, regionalism, individualism, and thus a pluralisation of life styles, which, accompanied by a high degree of intemational interconnections, avoid the traditional nationalism. The new Länder obviously draw their self-consciousness not from a common identity in the sense of a new national, westernised feeling, but from their single state identity, which could lead to a revival of a traditionally strong federalism. Authors like Stephan Hermlin, Utz Rachowski, Werner Liersch, Chaim Noll or Kurt Drawert seeked their identity by looking back into the past, and by doing so they foster this Heimatbewußtsein. This was extremly important in a period when many feared the appearance of a new nationalism in Germany; it is, however, also important because it improves the chances of a "normalisation" since German Amerikabilder and the American Deutschlandbilder might be weakened by bilateral fixations in the long run.

On the other hand, this tendency has also led to a rather reserved attitude of many East Germans towards the "west-foreigner". "Getting along with the new situation" is a topic which has been treated by authors like Helga Königsdorf, Stefan Heym, F.C. Delius, Thomas Rosenlöcher, Volker Ebersbach and Kerstin Hensel in detail (Bundesministerium für Bildung und Wissenschaft, 1995:16). Most of their texts are critical and cautious; almost none of the new facts - the renovated supermarket, the freedom to travel, generally speaking: liberty - have been accepted without doubts, prejudices, or with uncritical praise. The real challenge is the "new Germany", which faces the authors in both West and East Germany. As Günter Grass has put it in a poem:

verschnupft das Land,

die Grippe sucht uns heim,

und:

auf Siegers Seite lebten wir

behütet und getrennt

(quoted in: Bundesministerium für Bildung und Wissenschaft, 1995:24).

This way of thinking contrasts with the political disintegration during the first years after unification and the great curiosity of the younger generation for the products and phenomena of West German, and American mass culture. 


\subsection{New cultural relations and institutions}

At the annual meeting of the American Newspaper Publishers Association in New York in 1992, Chancellor Kohl deliberately mentioned these relations in the first place. Kohl even said that he would make sure that "our common grounds in literature, fine arts, music, and in movies would continue to gain importance" (Bulletin, 1992-05-06 - see Kohl, 1992). In everyday culture, however, there is still - contrary to developments in the economic field - an overwhelming imbalance. In the 1994 German movie hit parade, for instance, only two movies were not American productions (Süddeutsche Zeitung, 1995-02-17).

In pop and rock music as well as in (mass-) literature, on the other hand, there is greater cultural diversity in the nineties. In youth culture and sports, the trends of the eighties have been continued. Travel between both countries is still booming. In 1994 Germans spent more than 4 billion DM in the US, ranking the country No. 6 on the scale of the most popular travelling countries (Süddeutsche Zeitung, 1995-03-27).

The most important impulses for bilateral cultural relations after unification came from the German Federal Government. In 1992 the Secretary of State, George Bush, agreed with Kohl's idea of founding a German-American Academy of Sciences. And in 1993 the Chancellor greeted the members of the newly established Academic Council, 15 public figures from each country, who had rendered outstanding services to science or politics of science. Its major task is to deal with those social and political topics that are relevant to both sides, and to provide "new impulses" to a deeper cooperation in the fields of social sciences and humanities (Bulletin, 1993-07-02 - see Anon., 1993).

All these efforts, of course, put emphasis on the integration of the new Lainder. The Federal Government and the Administration in Washington offer a variety of opportunities for the younger generation of the former GDR to get in touch with American politics and cultural programmes, from the Parlamentarische Patenschaftsprogramm of the Bundestag and the US Congress, to several Fulbright Commissions. In 1990 the German Marshall Fund of the United States opened an office in East Berlin. Almost at the same time the United States Information Agency (USIA) started its "International Visitors Program" and "New Leadership Program" (Das Parlament, 1992-04-10).

Also in 1990 the American top universities Georgetown, Berkeley, and Harvard started a new initiative. For more than 45 million DM, the Federal Government established the so-called "Centres of Excellence" at each university to "foster the close friendship between the two countries and the consciousness of its vital significance and importance" (Die Zeit, 1993-03-26). 
America was not far behind. Apart from economic activities, one has to mention the important work of the eight Amerika-Häuser. In no other country will one find similar institutions. Their broad spectrum of events includes jazz concerts and lectures by Toni Morrison or Susan Sontag (Das Parlament, 1993-12-10). And in American companies, "cultural sponsoring" has become fashionable as well, so that one may easily predict that the future of the German-American youth exchange will be determined by a successful combination of state-sponsored programmes and private initiatives (Das Parlament, 1990-09-21). The more interesting question in this context, however, is what role mass culture will play in forming new identities for East Germans after the Wall.

\subsection{The role of mass culture in new identities for East Germans}

The swift pace of change for East Germans in the late eighties provides us with a compressed version of the social and personal dislocations experienced by many people undergoing media saturation and forms of colonisation. In East Germany, too, America has presented itself as a series of icons, clichés of itself that leave their imprint everywhere - on T-shirts, on commercial images, on TV movies, and in the heads of the people, in their collective imagination. Through a host of mediating agencies, East German minds have soaked up a range of images of the America that Americans have built, the skylines of Manhattan and Chicago, and street scenes from San Francisco and Los Angeles. East Germans saw them in the modern mass media, in West German television before the Wende. Now they are appearing in newspaper photographs, in films, and on TV as well. If you speak to East Germans after their first trip to America, some will tell you that they had the same moments of recognition, of déja vu, as West Germans had after their first encounter with the US. They remember the places in America not only as places in their minds but also as fragments of TV news clips and movies that they have seen in Germany. Others will have different feelings, still paralysed with inferiority, or critical of the reality, having been passive viewers of the West's media image, with its lush commercials and large number of American series and movies. In other words, some feel a new sense of freedom, others feel only a change of imposed imagery; some feel great admiration for the "easy" way of life, others refuse it even after ridding themselves of the strong influence of the official DDR propaganda.

In an article entitled "My Bitter Love for America" Steve Fox (1993:198-208) presented voices of East German high school teachers and their students, whose coming of age took place as their state and much of their culture disappeared. For East Germans the process of becoming acquainted with the Western media was not a gradual one. Since 1989, residents of the new Lander have been exposed to whole new categories of information, any one of which constitutes 
overload for the unprepared. Altogether, the sudden impact of this flood is unimaginable in the West:

... free press, conversion of the education system to the West German model, gain and then loss of community-based TV, increased West German and American programming on TV and radio, media, outdoor and mailbox advertising, the whole complex of product endorsement and cross-media tie-ins, and membership in the CNN clip-based version of global reality (Fox, 1993:198).

Overnight, the "Ossies" had to learn what is significant, what is trivial, what can be ignored and what should be studied. And all of this came under a new regime that - unlike the Marshall Plan with its compunctions about interfering in internal affairs - has stripped the GDR of all institutions and replaced them with the West German model. In his indispensable book, After the Wall (1991), based on his major ethnographic study of the DDR 1987-1990, John Borneman reports that many East German residents used the term corporate takeover to describe what is officially called Unification (Bomeman, 1991:passim; also see Monthly Review, 1991-09:14-30).

Nevertheless, many people have approached Western and American mass media with unexpected ambiguities, ironies, anger and wit - unexpected as West Germans and other media were preoccupied with macro-level controversies portrayed from the West German point of view. In looking at what they have lost and gained, they see the West and its hegemonic cultures - German and US - in a new light, or rather in a series of new lights. In their complex observations about their speeded-up lives, they are "taking snapshots of disappearances", to use Borneman's phrase, pictures of their daily adjustments to life in the postmodern electronic environment (Borneman, 1991:17).

Obviously, younger people get their information from TV, interpreting it as a medium that focuses and selects from a vaster pool of data than they had to deal with. The older generation, on the other hand, seems to prefer newspapers, although there were no Western newspapers in the East before the Wende at all. All soaked up news and information immediately after the Wende, the younger people focusing on the new lifestyle awaiting them. It is interesting, however, to see how many people of all generations expressed feelings ranging between euphoria and resignation about the Western TV as their "window to the world": "I often listened to the radio or watched TV. It was a crazy time full of fear, dreams and excitement; ... the new type is a dangerous development because I believe that most of what we think has its source in the mass media and it's so easy to influence people" (Fox, 1993:201). 
East Germans had only limited knowledge of the extent to which American images and icons dominated West European popular culture, whether movies, film-theatre advertising packages, music, fast food, clothes, posters, comics, or toys. "Consequently", Fox remarks, "they are more conscious of this American content than the 'Wessies', who, having grown up immersed in it, seem to have forgotten the American origins" (Fox, 1993:202). And East Germans consciously watch more American-origin programming than the people in the West. The problem, however, is that they also model their lives on American icons, and these are not a "natural" part of their identification. American film figures, in a positive as well as in a negative sense, do have a much greater influence on their life.

There was much less identification of East Germans with Western advertising, although they were familiar with it. Advertisers soon found out that their "lifestyle" ads were inappropriate for people without a wide choice of lifestyles. What East Germans wanted was information about products and services that they have lacked so far. The advertisers complied, but, rusty in the technique, were patronising. The East Germans, on the other hand, reacted to this "Ossie advertising" with disgust; they started disliking advertising, though accepting the greater variety and price competition. The German Advertising Trade Association summarised the industry's market research on this phenomenon in a press release:

... the Ossie 'rise from the socialist valley of sorrow' was coming along nicely, and special ads for Eastern markets had been, anyway, only 'a stage, an irritation'. Ossies were now being approached simply as consumers from special niches, 'the high art of advertising' (Fox, 1993:203).

Young "Ossies" found those special niches in musical subcultures. As many claim this was the most personal involvement they could get from a media source. Of course this fits into Günter Grass" image of the "niche society" (Nischengesellschaft), where thriving, more or less independent niches may either support subversive voices or imply a feeling of (self)confidence and independence. Because many song texts deal with problems, it is a natural outlet for adolescents suddenly freed from a system that forbade argument between "comrades", not to mention open public dissent.

\section{Conclusion: Changing images of America}

An ambivalent feeling between attraction and admiration on the one hand, and refusal, even disgust on the other hand, is probably the most typical attitude towards America you will find in the new lënder in these days. Somewhere between these antipodes, East Germans have developed a much less euphoric and more down-to-earth attitude, which an East German teacher expressed very splendidly as follows: "A symbol of this change? McDonald's? No. The 
permanently smiling American always optimistic, saying 'How nice!' and 'Fantastic!' or 'You are welcome!' No. My personal symbol is that of an average American who respects other people whether they are black or Asian or American Indian" (Fox, 1993:208). There is no doubt that such critical, but also fresh looks through East German eyes will soon be focused on West German lives ruled by mass media and other American cultural imports.

\section{Bibliography}

Anon. 1993. Newspaper article. Bulletin: 58, Jul. 2.

Basler, O. 1930. Amerikanismus. Geschichte eines Schlagwortes. Deutsche Rundschau, 8:142-147, August.

Bormeman, J. 1991. After the Wall. New York : Basic Books.

Bundesministerium für Bildung, Wissenschaft, Forschung und Technologie. 1995. Von Abraham bis Zwerenz. Eine Anthologie zur geistig-kulturellen Einheit in Deutschland. 3 Volumes. Bonn : Comelsen.

Fox, S. 1993. My Bitter Love for America. In: Kroes, R, Rydell, R.W., Bosscher, D.F.J. (ed.) Cultural Transmissions and Receptions. American Mass Culture in Europe. Amsterdam : VU University Press. p. 198-208.

Frisch, M. 1957. Homo Faber. Frankfurt : Suhrkamp.

Irions, U. 1984. Archimedes und Vatermord. Ein anti-amerikanisches Pamphlet. Ästhetik und Kommunikation, 55:91-94.

Karasek, H. 1972. Ohne zu verallgemeinern. Ein Gespräch mit Peter Handke. In: Scharang, M. (ed.) Über Peter Handke. Frankfurt : Suhrkamp. p. 85-90.

Kohl, H. 1992. Deutsch-amerikanische Partnerschaft in Verantwortung für Europa und die Welt. Bulletin: 47, May 6.

Kroes, R. 1996. If you've seen one, you've seen them all. European and American Mass Culture. Urbana/Chicago: University of Illinois Press.

Lüdke, A., Marssolek, I., Von Saldern, A. 1996. Amerikanisierung. Traum und Alptraum im Deutschland des 20. Jahrhunderts. Stuttgart : Franz Steiner Verlag.

Malaparte, C. 1950. Die Haut. Karlsruhe : Stahlberg.

Mann, G. 1961. Vom Geist Amerikas. Stuttgart: Klett.

Mathias, L.L. 1953. Die Entdeckung Amerikas Hamburg : Rowohlt.

Mikos, L. 1987. Von Dallas bis Denver. Der Alltag, 4:61-69.

Mitscherlich, A., Mitscherlich, M. 1977. Die Unfähigkeit zu trauern. Grundlagen kollektiven Verhaltens. München : Piper.

Weidenfeld, W. 1996. Kulturbruch mit Amerika? Das Ende transatlantischer Selbstverständlichkeit. Gütersloh: Bertelsmann Stiftung 